$2020,21(1)$, pp. 106 - 113, DOI: 10.18038 /estubtda. 537352

\title{
ENVIRONMENTAL PERMIT PROCESS ON EMISSIONS OF ASPHALT PLANT
}

\author{
Züleyha BİNGÜL ${ }^{1,}$, , Aysun ALTIKAT ${ }^{2}$ \\ ${ }^{1}$ Department of Environmental Engineering, Engineering Faculty, Iğdır University, Iğdır, Turkey \\ 2 Department of Civil Engineering, Engineering Faculty, Iğdır University, Iğdır, Turkey
}

\begin{abstract}
Asphalt plants are the facilities wherein the coating material on the roads, which vehicle traffic flows on it and is known as asphalt by most people, is produced. Asphalt plants bring significant environmental problems if necessary, precautions are not taken during production. The most important of these problems are the emissions of dust and gas which are emitted to the atmosphere and cause air pollution. In this study, emissions of an asphalt plant with a production capacity of 30 tons per hour and working 8 hours a day were measured in order to keep the pollutant effect on the atmosphere under control and to keep it at minimum level and the results of the measurement were evaluated within the scope of Industrial Air Pollution Control Regulation. Precipitated dust was carried out at two points for two months and particulate matter measurement was performed at three points in the plant. The precipitated dust values were $450 \mathrm{mg} \cdot \mathrm{m}^{-2}$.day ${ }^{-1}$ and the $\mathrm{PM}_{10}$ concentration was below $3 \mathrm{mg} \cdot \mathrm{N}^{-1} \cdot \mathrm{m}^{-3}$. The total mass flow rate of dust emissions from the loading, unloading, storage and transportation operations of the plant is $0.4431 \mathrm{~kg} \cdot \mathrm{h}^{-1}$. The total mass flow values of the emissions from the chimney to the atmosphere are $0.0826,13.915,7.26$, and $0.783 \mathrm{~kg} . \mathrm{h}^{-1}$ for dust, $\mathrm{CO}, \mathrm{SO}_{2}$, and $\mathrm{NO}_{2}$ emissions, respectively. According to the results, the dust and gas emissions of the sources in the plant provide the limit values specified in the regulation and there is no harm in granting environmental permission on emission.
\end{abstract}

Keywords: Asphalt production, Emission, Environmental pollution, Air pollution, Environmental permit

\section{INTRODUCTION}

While asphalt is used initially to prevent dust from vehicles moving on the surface layer without tethered, today it is widely used in the covering of roads, airports and open spaces for traffic and on concrete and steel bridges that serve vehicle traffic.

The asphalt production plant can be regarded as an industry line with production and application equipment, which include from bitumen and bituminous binders as the main component to various additives, from cold mixes to bituminous hot mix and surface coatings [1,2]. Bituminous hot blends on urban roads and high-traffic roads, surface coatings on low-traffic roads, rigid (concrete) coatings in the construction of airfields, hot mix asphalt on connection roads and taxis are used.

\subsection{Working System of Asphalt Plant}

During asphalt production, dried and heated aggregate at $145-160^{\circ} \mathrm{C}$ is mixed with bitumen which is heated to about the same temperature and made into viscous liquid in a mixer and is ready to be laid. The aggregate and bitumen ratios of the mixture are about $95 \%$ of the mixture is aggregate $5 \%$ is bitumen, while vary depending on the layer and layer characteristics. The used aggregate consists of crushed stone, crushed gravel or a mixture of these, and must satisfy the specified criteria [3-6]. The broken aggregate in the crushers is poured into the bunkers after they are separated according to their dimensions. It is spilled into the plant mixer by taking the desired amount of each material through the weigher under the bunkers. While the aggregate is poured into the plant mixer, the hot bitumen is mixed for a certain period of time by spraying into the mixer, and at the end of the mixing, the mixture is poured into the truck damper or hot product stock bunker car by opening the mixer bottom cover. Then

*Corresponding Author: zuleyha.bingul@igdir.edu.tr

Received: 08.03.2019 Published: 31.03.2020 
the process is completed by paving and compacting equipment by moving the road (Figure 1). It can be used for special additives which increase the binding according to the country conditions in the plant mixer and provide resistance to outdoor conditions. All the described operations are carried out through computer programs in the automated system of the plant. Everything is automatically managed from the operator's cab. Outputs from the plant computer show the types of aggregates, bitumen, filler and other additives used in the mix and daily material consumptions. The dimensions of the dryer, the burner capacity, the mixer capacity and the average mixing duration specify the capacity of the asphalt plant.

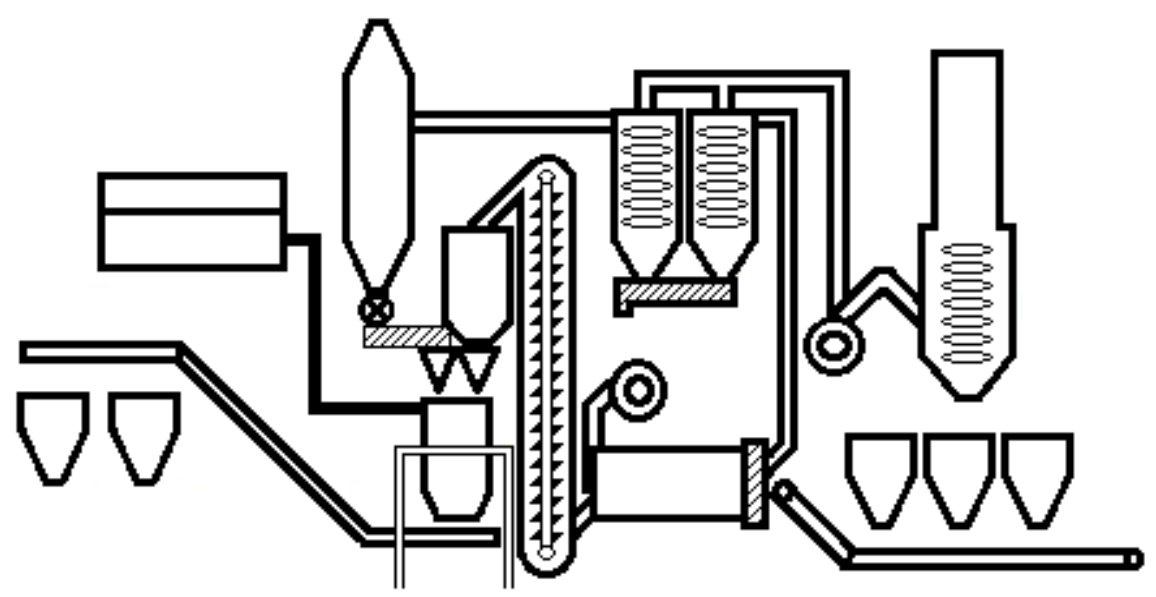

Figure 1. Scheme of an asphalt plant

Asphalt production sector has a variety of environmental impacts as it is not only produced but also used raw materials and energy. The most important environmental impact of asphalt plant facilities is dust and gas emissions to the atmosphere [7-9]. These facilities have both point and area emission sources. The area resources constitute the storage of the aggressor used in asphalt production, bunker, conveyor, conveyor belts and in-plant roads. The point sources are the combustion boiler flue resulting from the incineration system and the asphalt plant flue originating from the process $[2,3]$. Asphalt is a mixture containing thousands of different chemicals. The chemicals in asphalt vary depending on the source of crude oil, the type of bitumen used and the process [10]. Emissions from asphalt plant generally include carbon monoxide, nitrogen oxides, sulfur dioxide, volatile organic compounds and polycyclic aromatic hydrocarbons [3], [11-13]. A number of legal arrangements have been made to prevent, reduce and control the adverse effects of these emissions, which disrupt the air quality by altering the composition of the air, on human and environmental health. In Turkey, the Environmental Permit and License Regulation is also one of the legal regulations to reduce and control the environmental impacts of the activities and facilities that are polluting the environment. Article 11 of the Environmental Law No. 2872 which is aiming to ensure the protection of environment, the common asset of all living things, in accordance with sustainable environment and sustainable development principles contains the following provision: "Facilities and enterprises, that are not considered appropriate to discharge their wastes generated during production, consumption and service activities in directly or indirectly to the receiving environment, and settlement units are obliged to treat and dispose of their wastes in accordance with the standards and methods determined in the regulations and to obtain the permits envisaged". In this respect, the Environmental Permit and License Regulation prepared based on the Environmental Law was also published in the Official Gazette No. 29115 dated 10 September 2014 and entered into force on 1 November 2014.

Environmental Permit expresses the permit which is to be taken under the Environmental Law about at least one of the following: emissions, discharge, noise control, deep sea discharge and hazardous substance discharge. The Environmental Permit and License Regulation regulates the procedures and principles in the process of environmental permitting and licensing, the activities and facilities in this Regulation are also obliged to obtain environmental permits. According to the Environmental Permit 
and License Regulation, "Asphalt plants (including tar melting and spraying facilities), which prepare road material for more than one year in the place established, and the other facilities that melt and produce bitumen with mineral materials or tar mixture" are subject to environmental permit.

This study also examined the environmental permit process for emissions of this sector for providing to remain in control and minimize the atmospheric pollutant effect of asphalt plant facilities which has a production capacity of 30 tons per hour and works 8 hours per day in Turkey during operation. There are many studies in the literature on the environmental impacts of production facilities [14-17] or environmental regulations of countries have been processed [18-21]. However, examples of the implementation of the regulations do not have a counterpart in the literature. The aim of the study is to reveal the inspection process of an asphalt plant that creates environmental risk and therefore needs environmental permit and renewed periodically.

\section{MATERIALS AND METHODS}

\subsection{Study Site}

In this study, the emission results of an asphalt plant running 8 hours per day and producing 30 tons per hour were used. There are an asphalt plant and a thermal oil boiler with $750.000 \mathrm{kcal} / \mathrm{h}$ thermal power. Fuel oil is used as fuel in the plant. Plant flue is detached and $13 \mathrm{~m}$ above the ground. There is also a vertical outlet flue connected to the boiler. There are one four-bin bunker and one conveyor belt in the plant and they are covert. The stock materials are stored in a closed area. Inland roads are covered with gravel in the plant.

\subsection{Methods}

Sampling and analysis methods used in the measurement of emissions from pollutant sources are given in Table 1. After standardization by Turkish Standards Institute (TSE) and notified by the Ministry, the methods which were approved for acceptance were used in the measurements. If TSE standard is not available, Environmental Protection Agency (EPA) standards whose reliability accepted by the Ministry have been applied.

Table 1. Sampling and analysis methods used in emission measurements

\begin{tabular}{|l|l|l|}
\hline Measured Parameter & Analysis Method & Used Standard \\
\hline Precipitated dust & Gravimetric method & TS 2341:1976 \\
\hline Particulate matter-PM 10 & Gravimetric method & EPA 40 CFR PART 50 \\
\hline $\mathrm{CO}, \mathrm{O}_{2}$ & Electrochemical cell method & TS ISO 12039:2005 \\
\hline $\mathrm{SO}_{2}$ & Electrochemical cell method & TS ISO 7935:1999 \\
\hline $\mathrm{NO}_{2}$ & Electrochemical cell method & EPA CTM-022:1998 \\
\hline Dust & Gravimetric method & TS ISO 9096:2004, \\
\hline Sootiness & Color comparison & TS 9503:1991 \\
\hline Flue gas speed & Pitot tube method & TS ISO 10780:1999 \\
\hline Volatile organic compounds & Chromatographic method & TS EN 13649:2003 \\
\hline
\end{tabular}

In this study, dust and gas emissions and particulate matter measurement results in the operation phase of the 30 tons per hour capacity asphalt plant were evaluated according to the limit values specified in the Control of Industrial Air Pollution Regulation (CIAPR) on the basis of the environmental permit on emission required in accordance with the Environmental Permit and License Regulation. The Environmental Permit and License Regulation regulates the procedures and principles to be followed in the environmental permit and license process. The aim of CIAPR is to control the atmospheric emissions of fume, smoke, dust, gas, steam and aerosols occurring from operational activity of industries and energy production facilities; to determine the principles and procedures about protecting the people and the environment from the hazards by pollution in air, avoiding the adverse effects that 
cause significant harm to community and the neighborhood relations due to air pollution, and preventing to occur of these effects.

\section{RESULTS AND DISCUSSION}

Asphalt plant is supplied two types of pollutant to atmosphere, namely, dust and gas emissions [2224]. In asphalt plants, dust emission occurs during the discharging of raw material to the storage area, waiting at the storge area and transporting to bunker. Carrier belts and on-site roads are other sources of dust emissions in the plant. In the asphalt plant with a production capacity of 30 tons per hour, the mass flow rate of dust emission from loading, transportation, unloading and storage operations was calculated by using controlled emission factors in the CIAPR and given in Table 2 . The material is stored in an area of 0.1 ha for 24 hours. $3 \mathrm{~km}$ of road is used during the transportation of the material to the bunker.

Table 2. Total emission flow from all areas without flue.

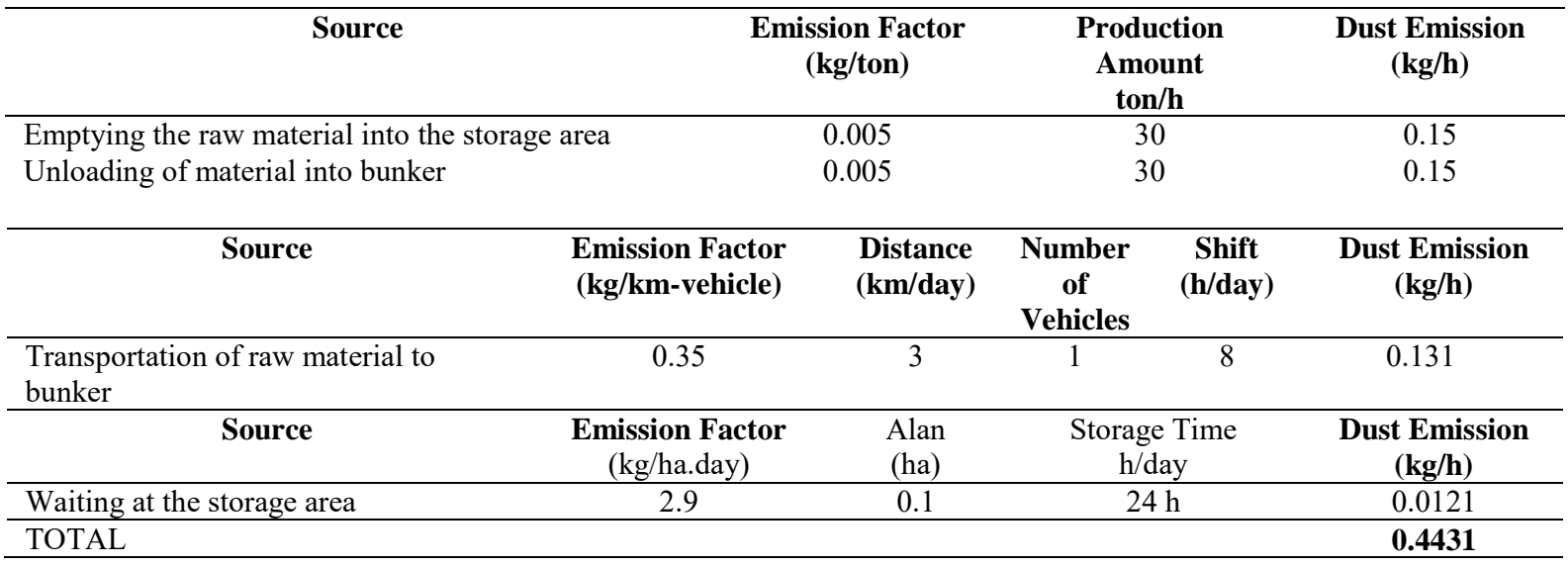

According to the CIAPR, the hourly mass flow rate limit for dust emission from places other than the flue is $1 \mathrm{~kg}$ /hour and since the limit value is not exceeded in the plant as seen in Table 2, there is no need to calculate the Air Pollution Additive Value of emissions in the plant impact area. However; CIAPR contains the following provision: while filling, separation, sieving, transportation, crushing and grinding of grain sizes greater than 5 millimeters in diameter happened in fixed installations and in open areas, the average amount of sediment dust measured per month cannot exceed the value of 450 $\mathrm{mg} / \mathrm{m}^{2}$-day by taking into account the dominant wind direction within the operation area according to the principles specified for the facilities where dust emissions originate from all areas without flue. For this reason, deposited dust measurement was made at two points in the facility. The measurement results are given Table 3 . The results show that the deposited dust does not exceed the limit values.

Table 3. Deposited dust measurement results

\begin{tabular}{lcccc}
\hline Measurement Place & $\begin{array}{c}\text { I. Measurement } \\
\left(\mathbf{m g} / \mathbf{m}^{2} \text {-day }\right)\end{array}$ & $\begin{array}{c}\text { II. Measurement } \\
\left(\mathbf{m g} / \mathbf{m}^{\mathbf{2}} \text {-day }\right)\end{array}$ & $\begin{array}{c}\text { Average Value } \\
\left(\mathbf{m g} / \mathbf{m}^{2} \text {-day }\right)\end{array}$ & $\begin{array}{c}\text { Limit Value } \\
\left(\mathbf{m g} / \mathbf{m}^{2} \text {-day }\right)\end{array}$ \\
\hline Entry point & 255 & 237 & 246 & 450 \\
Opposite storage point & 245 & 269 & 257 & 450 \\
\hline
\end{tabular}

In addition, according to CIAPR "prevention of dust emission from the facilities where filling, separation, sieving, transportation, crushing, grinding processes of the materials having grain size $1 \mathrm{~mm} \leq$ diameter $<5 \mathrm{~mm}$ can be realized by using chemical dust suppression system or pressure pulverized water. In this case, taking into account the prevailing wind direction, the average hourly dust concentration (PM 10) at 3 meters from the powder source should not exceed $3 \mathrm{mg} / \mathrm{Nm}^{3}$ maximum." In accordance with this provision, particulate matter was measured at 3 points in and around the facility as specified in the legislation. Measurement results were $1.62 ; 1.22$ and 1.08 $\mathrm{mg} / \mathrm{Nm}^{3}$ and it were below the limit value specified in the Regulation (Table 4). 
Table 4. PM10 measurement results

\begin{tabular}{lcc}
\hline \multicolumn{1}{c}{ Measurement Place } & Results $\left(\mathbf{m g} / \mathbf{N m}^{\mathbf{3}}\right)$ & Limit Value $\left(\mathbf{m g} / \mathbf{N m}^{\mathbf{3}}\right)$ \\
\hline Bunker & 1.62 & 3 \\
In-plant roads & 1.22 & \\
Storage Area & 1.08 & \\
\hline
\end{tabular}

The bunker and the conveyor belt were covered in order to prevent dust in the plant, and the open storage materials were covered with a tarpaulin. The dust emissions in the plant are controlled with the use of closed transport systems, keeping the material moist, loading and unloading without winnowing, watering the inland roads and provided air quality standards in accordance with CIAPR.

The other emission sources in the asphalt plants are the plant flue and the combustion boiler flue which emit gas emissions. According to CIAPR, waste gases should be released to the atmosphere by vertical outlet so that they can be transported without being obstructed by the free air flow and flues should be used for this purpose. For plants with rated thermal power of more than $500 \mathrm{~kW}$, the velocity of the gases from the flue must be at least $4 \mathrm{~m} / \mathrm{s}$. For plants with the rated thermal power is between $500 \mathrm{~kW}$ and $1.2 \mathrm{MW}$, the height of the chimney should be at least $1.5 \mathrm{~m}$ from the highest point of the roof if the roof is inclined and at least $2 \mathrm{~m}$ from the highest point of the roof if it is flat.

The plant, which is evaluated within the scope of emission permit, has thermal oil boiler with 750,000 $\mathrm{kcal} /$ hour thermal power and fuel oil is used as fuel in it. The rated thermal power of the boiler is 0.87 MW. The roof of the thermal oil boiler is inclined and the flue of the emission source is $4 \mathrm{~m}$ from the roof and the flue gas outlet speed is $4 \mathrm{~m} / \mathrm{s}$. Flue height and gas outlet speed in the thermal oil boiler flue are provided the desired conditions in the regulation.

In the regulation, the facilities where the bitumen road construction materials are produced and processed are grouped as fourteenth group facilities. The facilities in this group should release waste gases from a flue with a height of at least $12 \mathrm{~m}$ to the atmosphere. The existing asphalt plant flue is $13 \mathrm{~m}$ long in the plant and the required $12 \mathrm{~m}$ height is met. The gas emission sources in the plant, emission results of asphalt plant flue are given in Table 5 and emission results of the thermal oil boiler flue are given in Table 6.

The limit values for organic steam and gas emissions in the Regulation are classified as I, II and III. According to this classification, total emissions of organic compounds present in waste gases in vapor and gas form cannot exceed $20 \mathrm{mg} / \mathrm{Nm}^{3}$ for organic compounds included in the Class I (for emission flows of $0.1 \mathrm{~kg} / \mathrm{h}$ and above), $150 \mathrm{mg} / \mathrm{Nm}^{3}$ for organic compounds included in the Class II (for emission flows of $3 \mathrm{~kg} / \mathrm{h}$ and above), and $300 \mathrm{mg} / \mathrm{Nm}^{3}$ for organic compounds included in the Class III (for emission flows of $6 \mathrm{~kg} / \mathrm{h}$ and above), even if there are more than one compound from the same class. According to the results of organic vapor and gas measurements made for the emission sources, the desired limit values in the plant have not been exceeded and circumstances have been met.

Table 5. Asphalt plant flue emission measurement results

\begin{tabular}{lccccc}
\hline Measured Parameter & $\begin{array}{c}\mathbf{1 .} \\
\text { Measurement }\end{array}$ & $\begin{array}{c}\mathbf{2 .} \\
\text { Measurement }\end{array}$ & $\begin{array}{c}\mathbf{3 .} \\
\text { Measurement }\end{array}$ & $\begin{array}{c}\text { Average } \\
\text { Limit } \\
\text { Value }\end{array}$ \\
\hline Gas Speed $(\mathrm{m} / \mathrm{s})$ & 13.478 & 15.424 & 19.22 & 16.10 & 4 \\
Fuliginous & 2 & 2 & 2 & 2 & 3 \\
Dust Concentration $\left(\mathrm{mg} / \mathrm{Nm}^{3} / \mathrm{O}_{2}\right)$ & 11.1 & 10.3 & 9.1 & 10.2 & 50 \\
Dust Emission $(\mathrm{kg} / \mathrm{h})$ & 0.0762 & 0.0777 & 0.0878 & 0.0806 & 10 \\
CO Emission $(\mathrm{kg} / \mathrm{h})$ & 11.851 & 13.151 & 16.624 & 13.875 & 50 \\
$\mathrm{SO}_{2}$ Emission $(\mathrm{kg} / \mathrm{h})$ & 5.78 & 6.41 & 8.13 & 6.77 & 60 \\
$\mathrm{NO}_{2}$ Emission $(\mathrm{kg} / \mathrm{h})$ & 0.591 & 0.669 & 0.849 & 0.703 & 20 \\
Toluene Concentration $\left(\mathrm{mg} / \mathrm{m}^{3}\right)$ & 0.0000894 & 0.0000983 & 0.0000235 & 0.0000704 & 100 \\
1.3-dichlorobenzene con. $\left(\mathrm{mg} / \mathrm{m}^{3}\right)$ & 0.0000006 & 0.0000007 & 0.0000002 & 0.0000005 & 100 \\
1.4-dichlorobenzene con. $\left(\mathrm{mg} / \mathrm{m}^{3}\right)$ & 0.0000261 & 0.0000983 & 0.0000235 & 0.0000493 & 100 \\
\hline
\end{tabular}


Table 6. The thermal oil boiler flue emission measurements results

\begin{tabular}{|c|c|c|c|c|c|}
\hline Measured Parameter & $\begin{array}{c}1 . \\
\text { Measurement }\end{array}$ & $\begin{array}{c}2 . \\
\text { Measurement }\end{array}$ & $\begin{array}{c}3 . \\
\text { Measurement }\end{array}$ & Average & $\begin{array}{l}\text { Limit } \\
\text { Value }\end{array}$ \\
\hline Gas Speed $(\mathrm{m} / \mathrm{s})$ & 6.61 & 6.96 & 6.65 & 6.74 & 4 \\
\hline Fuliginous & 3 & 3 & 3 & 3 & 4 \\
\hline Dust Concentration $\left(\mathrm{mg} / \mathrm{Nm}^{3} \mathrm{r} . \% \mathrm{O}_{2}\right)$ & 2.69 & 2.99 & 3.11 & 2.93 & 177 \\
\hline Dust Emission $(\mathrm{kg} / \mathrm{h})$ & 0.001 & 0.002 & 0.002 & 0.002 & 10 \\
\hline CO Concentration $\left(\mathrm{mg} / \mathrm{Nm}^{3} \%\right.$ ref. $\left.\mathrm{O}_{2}\right)$ & 88.65 & 87.19 & 90.18 & 88.67 & 150 \\
\hline CO Emission $(\mathrm{kg} / \mathrm{h})$ & 0.04 & 0.04 & 0.04 & 0.04 & 5 \\
\hline $\mathrm{SO}_{2}$ Concentration $\left(\mathrm{mg} / \mathrm{Nm}^{3 \%} \%\right.$ ref. $\mathrm{O}_{2}$ ) & 1107.53 & 1108.28 & 1107.53 & 1107.78 & 1700 \\
\hline $\mathrm{SO}_{2}$ Emission $\mathrm{kg} / \mathrm{h}$ ) & 0.48 & 0.51 & 0.48 & 0.49 & 60 \\
\hline $\mathrm{NO}_{2}$ Concentration $\left(\mathrm{mg} / \mathrm{Nm}^{3} \%\right.$ ref. $\left.\mathrm{O}_{2}\right)$ & 288.12 & 290.96 & 285.48 & 288.19 & 800 \\
\hline $\mathrm{NO}_{2}$ Emission $(\mathrm{kg} / \mathrm{h})$ & 0.08 & 0.08 & 0.08 & 0.08 & 20 \\
\hline
\end{tabular}

In addition, the emission of dust in the waste gases of the fourteenth group which includes asphalt plant facilities shall not exceed $50 \mathrm{mg} / \mathrm{Nm}^{3}$ based on $4 \% \mathrm{CO}_{2}$ in combustion gases according to CIAPR. For asphalt concrete preparation and similar processes, dust emission should not exceed $50 \mathrm{mg} / \mathrm{Nm}^{3}$. The result of the measurement made for the asphalt plant flue by making $4 \% \mathrm{CO}_{2}$ correction, the dust emission was found $10.2 \mathrm{mg} / \mathrm{Nm}^{3}$ and is below the limit value of $50 \mathrm{mg} / \mathrm{Nm}^{3}$ specified in the legislation. Flues are regularly cleaned and maintained. There is a dust filter system in the asphalt plant oven flue. These filters are emptied by a closed system and the filters that have expired are replaced.

According to CIAPR, the fuel heat capacity in the fuel oil plants up to $2 \mathrm{MW}$ cannot exceed $3 \%$ fuel biodiesel burners and in fuel oil which contain 1.5\% sulfur based on Bacharach scale and not exceed $4 \%$ in 6 no-fuel oil burners. In the flue gas based on $3 \%$ of the volumetric oxygen content $\mathrm{CO}$ emission, $\mathrm{NO}$ and $\mathrm{NO}_{2}$ emissions (in $\mathrm{NO}_{2}$ ), and $\mathrm{SO}_{2}$ emissions cannot exceed the limit values as 150 $\mathrm{mg} / \mathrm{Nm}^{3}, 800 \mathrm{mg} / \mathrm{Nm}^{3}$, and of $1700 \mathrm{mg} / \mathrm{Nm}^{3}$ respectively. As seen in Table 6 , none of the pollutant emissions in the waste gases released to the atmosphere from the flue of the thermal oil boiler which has a thermal power of $0.87 \mathrm{MW}$ did not exceed the limit values specified in the regulation.

According to CIAPR, the hourly mass flow rates of the emissions from the flues to the atmosphere should be determined by measuring in flues for the plants. Table 7 shows the hourly mass flow rates and the limit values of the emissions from the flue to the atmosphere. If the limit values given in Table 7 are exceeded, the Air Pollution Additive Value of the emissions in the plant impact area should be calculated. As it can be seen from the table, the total mass flows of the emissions from the flue to the atmosphere do not exceed the limit values given in the regulation and provide the air quality conditions.

Table 7. Mass flow value of pollutants

\begin{tabular}{lcc}
\hline Pollutant type & Emisyon (kg/h) & Limit Value (kg/h) \\
\hline $\mathrm{CO}$ & 13.915 & 500 \\
$\mathrm{SO}_{2}$ & 7.26 & 60 \\
$\mathrm{NO}_{2}$ & 0.783 & 40 \\
Dust (Flue) & 0.0826 & 10 \\
Dust (all areas without flue) & 0.4431 & 1 \\
Total Volatile Organic Compounds & 0.000001 & 30 \\
\hline
\end{tabular}

In this context, since the dust and gas pollutant emissions in the waste gases of the emission flues in the plant do not exceed the limit values specified in the regulation, there is no need for continuous measurement of dust and flue gas emissions.

\section{CONCLUSION}

In order to prevent, reduce and control the dust and gas emissions that disrupt the air quality by releasing from the asphalt plants into the atmosphere, the plant operators obtain the environmental 
permission by providing the emission standards in the CIAPR and save the asphalt plants from being a threat to human and environmental health. In this study, the environmental permitting process of an asphalt plant with an hourly production capacity of 30 tons was evaluated. According to the emission measurement results from the asphalt plant flue and thermal oil boiler flue as the point source, and measurement results from the area source, dust and gas emissions in the emission sources in the plant provide the limit values specified in the regulation. In these circumstances, it is appropriate to give an environmental permit on the emission issue. The period of this permit is 5 years and if the operation site of the plant is changed, the fuel or combustion system is changed, the production capacity or the burning / rated thermal power shall be increased by $1 / 3$ and the plant does not work for 3 years, the permit process must be restarted.

\section{REFERENCES}

[1] Umwelt (Australia) Pty Limited on behalf of Downer Group. Environmental impact statement for mobile asphalt plant. Oberon, Australia. 2015.

[2] Moretti L, Di Mascio P, D'Andrea A. Environmental Impact Assessment of Road Asphalt Pavements. Modern Applied Science, 7(11), 1-11, 2013.

[3] Ruiz MP, Acevedob PA, Puelloc J. Evaluation of The Environmental Impact of a Dense Graded Hot Mix Asphalt (HMA). Chemical Engineering Transactions, 36, 229-234, 2014.

[4] Rilwani ML, Agbanure FE. An assessment of the environmental impact of asphalt production in Nigeria. Anthropologist, 12(4), 277-287, 2010.

[5] Sera Measurement Analysis Environment Laboratory. 12th Regional Directorate of Highways, Emission Measurement Report of Oltu Asphalt Plant. Oltu, Erzurum, Turkey, 2014.

[6] National Asphalt Pavement Association. The Environmental Impact of Asphalt Plants. Lanham, 2014.

[7] Kennepohl GJA. Asphalt pavements and environment. ISAP International Symposium on Asphalt Pavements and Environment, Zürich, Switzerland, 2008.

[8] Yang R, Ozer H, Kang S, Al-Qadi I. Environmental Impacts of Producing Asphalt Mixtures with Varying Degress of Recycled Asphalt Materials. International Symposium on Pavement LCA 2014. Davis, California, USA, October 14-16, 2014.

[9] Ceylan H. Relationship between environmental law and asphalt industry. Erciyes University Journal of Institute of Science and Technology 25, (1-2), 71-98, 2009.

[10] Mouwerik MV, Stevens L, Seese MD, Basham W. Environmental Contaminants Encyclopedia Asphalt Entry. National Park Service Water Resources Divisions, Water Operations Branch, 1201 Oakridge Drive, Suite 250, 1997.

[11] Amidon K. Hot Mix Asphalt Emissions. State of Oregon Department of Environmental Quality, Air Quality Division Western Region 2013.

[12] Green LC. Questions and Answers Regarding Hot Mix Asphalt Plants and Environmental and Public Health Considerations. Cambridge Environmental Inc, 2008. 
[13] Missouri Department of Natural Resources Environmental Assistance Office. Preventing Pollution at Hot Mix Asphalt Plants, A Guide to Environmental Compliance and Pollution Prevention for Asphalt Plants in Missouri. Jefferson City, Missouri, 2004.

[14] Prylypko VA, Morozova MM, Bondarenko IV, Petrychenko OO, Romanenko OM, Tuz KK, Ozerova YY, 2019. Impact of The Rivne NPP Activity on Natural and Social Environment of The Control Area. Probl Radiac Med Radiobiol. 2019 Dec; 24:131-149. doi: 10.33145/2304-83362019-24-131-149.

[15] Puettmann M, Sinha A and Ganguly, I. Life Cycle Energy and Environmental Impacts of Cross Laminated Timber Made with Coastal Douglas-Fir. Journal of Green Building: Fall 2019, Vol. 14, No. 4, pp. 17-33. https://doi.org/10.3992/1943-4618.14.4.17.

[16] Koç, K. Formaldehyde Emissions and Effects on Health During Arrival of Furniture to Ultimate Consumer. Wood Industry and Engineering 2019, Volume: 01 Number: 01 Pages: 14-19.

[17] Cole MA, Elliott RJR, Shimamoto K. Industrial characteristics, environmental regulations and air pollution: an analysis of the UK manufacturing sector. Journal of Environmental Economics and Management Volume 50, Issue 1, July 2005, Pages 121-143.

[18] LOC (The Law Library of Congress), 2018. Regulation of Air Pollution Australia, Brazil, Canada, China, European Union, France, Israel, Japan, South Africa, Switzerland, United Kingdom. The Law Library of Congress, Global Legal Research Center. June 2018. Acosta, L (editor), law@loc.gov.

[19] WHO (World Health Organization), 2017. Evolution of WHO air quality guidelines: past, present and future. Copenhagen: WHO Regional Office for Europe. ISBN 9789289052306;

[20] Wheeler D, 2001. Racing to the Bottom? Foreign Investment and Air Pollution in Developing Countries. Policy Research Working Paper;No. 2524. World Bank, Washington, DC. C) World Bank.

[21] Gray WB, Deily ME. Compliance and Enforcement: Air Pollution Regulation in the U.S. Steel Industry. The Journal of Environment \& Development; Journal of Environmental Economics and Management Volume 31, Issue 1, July 1996, Pages 96-111

[22] European Asphalt Pavement Association. Environmental Guidelines on Best Available Techniques (BAT) for the Production of Asphalt Paving Mixes. Brussels, Belgium, 2007.

[23] Environmental Protection Branch, Saskatchewan Ministry of Environment. Environmental Guideline for Saskatchewan Asphalt Plants. Government of Saskatchewan, 2015.

[24]EPA. Hot mix asphalt plants emission assessment report. United States Environmental Protection Agency Office of Air and Radiation Office of Air Quality Planning and Standards, Research Triangle Park, North Carolina, 2000. 